\title{
From suspicion of angioedema to the diagnosis of lung cancer
}

\section{Łukasz Moos, Wojciech Żurek, Katarzyna Kapeluszna, Zenon Brzoza}

Department of Internal Medicine with Division of Allergology, Institute of Medical Sciences, University of Opole Head of the Department: Zenon Brzoza

\section{Correspondence:}

Łukasz Moos

Department of Internal Medicine with Division of Allergology, Institute of Medical Sciences, University of Opole, Poland 45-401 Opole, al. Wincentego Witosa 26

phone: 774520604

e-mail: lukasz.moos@uni.opole.pl

Received: 9.09.2020

Accepted:

25.10.2020

DOI: 10.24292/01.OR.320251020 Copyright $\odot$ Medical Education. All rights reserved.

\section{ABSTRACT}

Angioedema is a localized and self-limiting oedema of the subcutaneous and submucosal tissue. Case presentation: 73-year-old man was admitted to the Division of Allergology with the diagnosis of angioedema. Detailed physical examination led to the suspicion of superior vena cava syndrome with secondary face swelling. Biopsy revealed metastasis of small cell carcinoma in superclavicular lymph nodes.

Conclusions: Facial swelling, especially recurrent and non-inflammatory, is often, but not always caused by angioedema. Insightful differential diagnosis is crucial before making the final one.

Key words: angioedema, $A A E, H A E$, superior vena cava syndrome, lung cancer 


\section{INTRODUCTION}

Facial oedema, particularly recurrent, requires extensive differential diagnosis. In this description we present a patient referred to the Department of Internal Medicine with Division of Allergology at the University Clinical Hospital in Opole from the Dermatological Outpatient Clinic with a diagnosis: angioedema. Possible causes of facial oedema, apart from angioedema, with brief characteristics are presented in table 1 [1-4]. Angioede$m a$ is a disease of the skin and mucous membranes defined as self-limiting tissue oedema associated with increased vascular permeability - secondary to the release of vasoactive mediators. European Academy of Allergy and Clinical Immunology (EAACI) distinguishes 4 types of acquired angioedema (AAE) and 3 types of hereditary angioedema (HAE) (tab. 2) unrelated to wheals (and thus unrelated to urticaria) [1].

TABLE 1.

Causes of facial oedema in the differential diagnosis of angioedema.

\begin{tabular}{|c|c|}
\hline Causes & Selected characteristic features \\
\hline Lymphomas & $\begin{array}{l}\text { - usually accompanying general } \\
\text { symptoms } \\
\text { - erythroderma in Sezary's syndrome } \\
\text { - histopathological evaluation (with } \\
\text { immunohistochemical examination) is } \\
\text { crucial }\end{array}$ \\
\hline $\begin{array}{l}\text { IgG4-dependent } \\
\text { disease }\end{array}$ & $\begin{array}{l}\text { systemic disease, usually associated } \\
\text { with swelling of the eyelids and } \\
\text { salivary glands, may be responsible } \\
\text { for pancreatitis, retroperitoneal } \\
\text { fibrosis, cholangitis, thyroiditis, aortic } \\
\text { inflammation } \\
\text { - an elevated lgG4 titre is found, } \\
\text { in histological-pathological evaluation: } \\
\text { lymphocyte infiltration, plasma cells } \\
\text { infiltration, fibrosis, IgG4+ cell infiltration }\end{array}$ \\
\hline $\begin{array}{l}\text { Contact } \\
\text { dermatitis }\end{array}$ & $\begin{array}{l}\text { - key: interview towards exposure to } \\
\text { provocative factors } \\
\text { - accompanied by itching, possible skin } \\
\text { swelling and erythematous changes }\end{array}$ \\
\hline Hypothyroidism & $\begin{array}{l}\text { - significant oedema usually in severe } \\
\text { organ failure } \\
\text { the assessment of thyroid function is } \\
\text { crucial }\end{array}$ \\
\hline Angioedema & $\begin{array}{l}\text { - limited non-inflammatory oedema } \\
\text { - usually disappears within } 24-72 \mathrm{~h} \\
\end{array}$ \\
\hline Dermatomyositis & $\begin{array}{l}\text { - may be accompanied by general } \\
\text { symptoms: pain and arthritis, muscle } \\
\text { pain, dysphagia, lung fibrosis } \\
\text { - possible accompanying symptoms: } \\
\text { Raynaud's symptom, Gottron's symptom } \\
\text { and lumps, heliotropic erythema }\end{array}$ \\
\hline $\begin{array}{l}\text { Orbital soft tissue } \\
\text { inflammation }\end{array}$ & $\begin{array}{l}\text { - usually unilaterally, with painful } \\
\text { erythema } \\
\text { - accompanied by fever and headaches }\end{array}$ \\
\hline $\begin{array}{l}\text { Melkersson- } \\
\text {-Rosenthal } \\
\text { syndrome }\end{array}$ & $\begin{array}{l}\text { - typical facial oedema without erythema } \\
\text { (recurrent or chronic) } \\
\text { - accompanied by an undulating tongue, } \\
\text { facial nerve paralysis }\end{array}$ \\
\hline
\end{tabular}

\begin{tabular}{|l|l|}
\hline $\begin{array}{l}\text { Nephrotic } \\
\text { syndrome }\end{array}$ & $\begin{array}{l}\text { usually dominated by eyelid oedema } \\
\text { key: determination of kidney function } \\
\text { parameters }\end{array}$ \\
\hline Sjögren's syndrome & $\begin{array}{l}\text { possible oedema of the parotid } \\
\text { gland, swelling of the eyelids may be } \\
\text { accompanied by erythematous changes } \\
\text { accompanied by dry eyes, lips, joint } \\
\text { complaints }\end{array}$ \\
\hline Superior vena cava & $\begin{array}{l}\text { ANA antibodies usually present: anti-Ro } \\
\text { (SS-A), anti-La (SS-B) }\end{array}$ \\
\hline syndrome & $\begin{array}{l}\text { often accompanied by swelling in the } \\
\text { neck in addition to facial oedema } \\
\text { symptoms of collateral circulation on } \\
\text { the skin of the chest }\end{array}$ \\
\hline
\end{tabular}

TABLE 2.

Classification of angioedema according to the European Academy of Allergy and Clinical Immunology (EAACl).

\begin{tabular}{|l|l|}
\hline \multicolumn{1}{|c|}{ Acquired } & \multicolumn{1}{c|}{ Hereditary } \\
\hline - $\begin{array}{l}\text { related to ACE-I use } \\
\text { related to C1-INH } \\
\text { deficiency }\end{array}$ & $\begin{array}{l}\text { - related to C1-INH deficiency } \\
\text { related to the mutation of factor } \\
\text { XIl gene of the coagulation }\end{array}$ \\
$\begin{array}{l}\text { - idiopathic histaminergic } \\
\text { idiopathic non- } \\
\text {-histaminergic }\end{array}$ & - unknown aetiology \\
\hline
\end{tabular}

ACE-I - angiotensin converting enzyme inhibitors, $\mathrm{C} 1-\mathrm{INH}$ - complement $\mathrm{C1}$ inhibitor.

\section{CASE PRESENTATION}

A 73-year-old patient without previously diagnosed chronic diseases, a longstanding cigarette smoker, was referred from the Dermatological Outpatient Clinic due to persistent facial oedema as angioedema.

The patient's history reported a symmetrical facial swelling (fig. 1) with redness of the skin, occurring one month before and persisting, without any improvement after the recommended external glicocorticosteroids or oral antihistamines.

FIGURE 1.

Swelling of the patient's face.

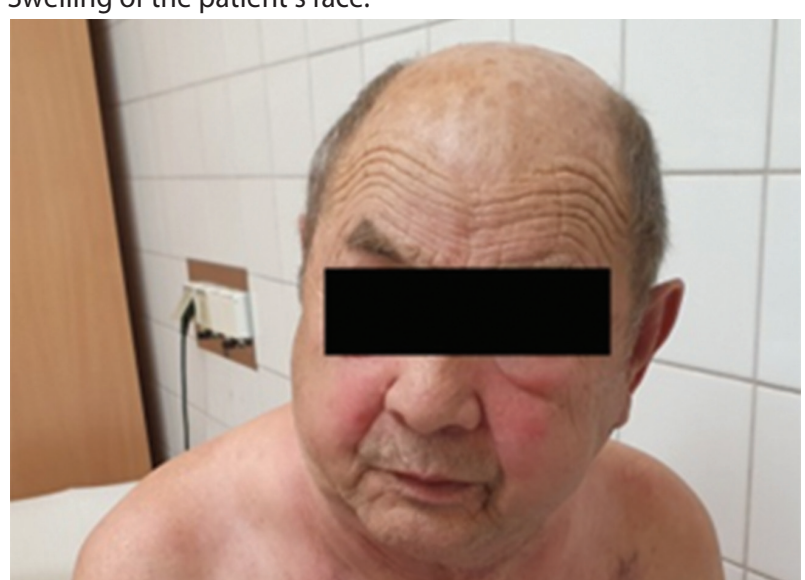


Additionally, the patient observed dilated veins of the chest skin (fig. 2), the occurrence of a large nodular lesion in the supraclavicular area on the right side and dizziness during upright standing, as well as periodically occurring dyspnoea. The patient denied skin itching, abdominal pain, occurrence of urticaria wheals or infections in the recent past.

FIGURE 2.

Collateral circulation on the skin of the chest.

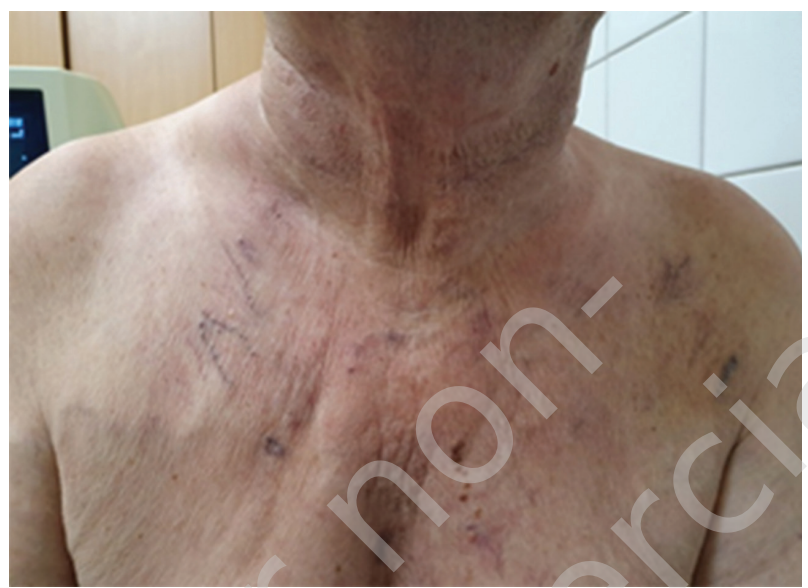

The physical examination was performed on admission to the hospital. Symmetrical oedema of the face and neck without clear demarcation from healthy skin was observed, additionally, a large tumour-like lesion of the lymph node bundle, immovable towards the base, in the right supraclavicular space. Vein dilatation was visible on the front skin of the chest. A symmetric vesicular murmur was heard over the lungs, heart rate was $75 / \mathrm{min}$, arterial pressure $120 / 60 \mathrm{mmHg}$. The abdominal palpation showed no pathological resistance. There were no peripheral oedemas on the lower extremities.

Laboratory tests showed measurably elevated CRP (13.55 mg/l), ESR (34 mm/h), without any other significant deviations. The patient underwent abdominal USG and chest X-ray to detect dilation of the upper mediastinum, emphysema and small banded densities in the supradiaphragmatic parts of the lungs. Moreover, USG of the neck was performed to confirm the presence of lymph node bundles in the right supraclavicular and posterior triangle area of the neck, pathologically changed lymph nodes on the left side and internal jugular vein thrombosis with preserved narrow peripheral flow.

$\mathrm{CT}$ of the chest, neck and facial skeleton showed numerous bundles of lymph nodes with decay features, located in the medi- astinum, neck, supraclavicular areas and posterior neck triangles on both sides. In addition, numerous osteoblastic lesions have been found in the bones of the chest, facial and neck bones most probably of metastatic character (fig. 3, 4). The patient underwent oncologic consultation - he was not qualified for urgent mediastinal radiotherapy. Systemic steroid therapy with dexamethasone was applied, anticoagulant therapy was implemented. The patient was consulted with laryngologist, there were no significant abnormalities in the fiberoscopic image. Gastroscopy was performed and revealed the presence of upper oesophageal varices of $2^{\text {nd }}$ degree, erythematous gastropathy, duodenal cap ulcers. Specimens were taken from the stomach for histological-pathological examination, urease test was positive.

FIGURE 3.

Computed tomography image of the neck and chest (frontal plane reconstruction).

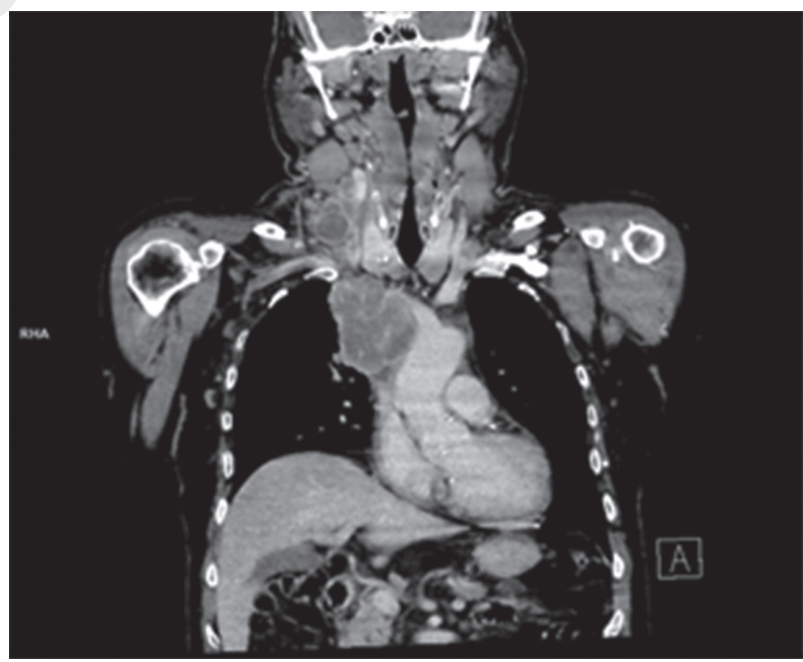

FIGURE 4.

Transverse computed tomography scan (the arrow points to the right internal jugular vein).

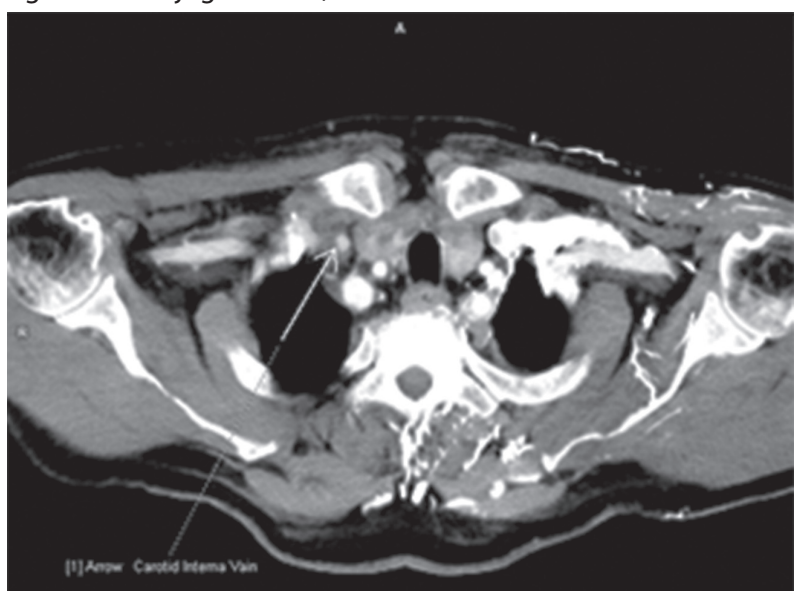


Under the conditions of the operating theatre, the node was taken from the right supraclavicular area - metastases of small cell lung cancer were described in the histological image. Having fixed the date of urgent admission to the lung diseases ward, the patient was discharged with Helicobacter pylori eradication therapy followed by proton pump inhibitor treatment, anticoagulant therapy and systemic glicocorticosteroid therapy.

\section{DISCUSSION}

The most common form of angioedema is acquired idiopathic histaminergic angioedema (IH-AAE). The diagnosis is based on the clinical picture supported by a response to antihistamine treatment with exclusion of other causes of angioedema. The key to make the diagnosis is a detailed clinical assessment of the patient, which should set out a plan of additional examinations. While taking patient's history, performing physical examination and planning further diagnostics, the aim should be to exclude autoimmune diseases, infections, C1-INH deficiency, factor XII mutations. As part of the laboratory test panel, it is recommended to consider the determination of tryptase concentration (in cases with anaphylaxis), rheumatoid factor, antinuclear antibodies, C3 and C4 components of the complement system, anti-C1q antibodies (especially in cases of suspected autoimmune disease or urticarial vasculitis). The clinical manifestation of IH-AAE is a recurrent swelling of the skin and mucous membranes. No oedema of the gastrointestinal mucosa is observed. Antihistamines and systemic steroid therapy are effective [1].

Acquired angioedema associated with C1-INH deficiency in 94\% of cases occurs in patients over 40 years old. The family history is clear and the oedema usually affects the face, tongue, uvula, upper respiratory tract, and in a form located in different parts of the body. Less typical are the gastrointestinal tract symptoms [1]. Congenital angioedema is characterized by recurrent, borderline oedema of subcutaneous or submucosal tissue lasting 2-5 days. Most often these oedemas affect the skin, upper respiratory tract and gastrointestinal tract. The clinical image varies from asymptomatic to life-threatening cases. A common symptom is recurrent abdominal pain, often very severe - in the absence of a proper diagnosis, it may even cause unnecessary surgical intervention [1, 2].

In described case, the diagnosis of angioedema was denied uniform oedema of the entire face, with accompanying oedema of the neck, without clear demarcation and persisting chronically without recurrent character, spoke against. The patient did not report any gastrointestinal complaints and did not observe any improvement despite the antihistamines used. The family history for angioedema was negative. The attention was also drawn to the large lymph node bundle in the right supraclavicular region and an extensive network of veins on the chest skin - symptoms that are not typical for angioedema.

One of the rare causes of facial oedema is superior vena cava syndrome. Lung cancers and lymphomas are responsible for most of the causes (tab. 3) [5]. The histopathological evaluation of the sampled lymph node, proved to be conclusive in the case described, as the imaging did not show the mass of the tumour, but only indirect features of the proliferation process suggesting also possible lymph growth due to the multitude of metastatic lymph nodes. The main aim of the treatment of superior vena cava syndrome is to restore effective venous flow and to control the patient's annoying symptoms. Apart from systemic steroid therapy and symptomatic treatment of dyspnoea (morphine, midazolam, oxygen therapy), should be considered: urgent mediastinal irradiation, chemotherapy for chemically sensitive tumours, stent placement into the superior vena cava. The procedure changes over time, it is recommended to shorten the time of systemic steroid therapy, also attention is paid to the necessity of therapy individualization. In the case of lung cancer, a similar percentage of relief is observed regardless of the treatment strategy adopted (chemotherapy or radiotherapy) in both small and non-small cell carcinomas. In small cell carcinoma, chemotherapy brings relief in $84 \%$ of cases (with $17 \%$ relapse rate) and radiotherapy in $78 \%$ (with $19 \%$ relapse rate). In the case of non-small cell carcinoma, however, the percentage of objective improvement due to chemotherapy is significantly lower than in the case of small cell carcinoma (20-40\% vs. 50-80\%) [6, 7].

TABLE 3.

Causes of the superior vena cava syndrome.

\begin{tabular}{|l|c|l|c|}
\hline \multicolumn{2}{|c|}{ Cancerous [\%] } & \multicolumn{2}{c|}{ Non-cancerous [\%] } \\
\hline $\begin{array}{l}\text { non-small cell lung } \\
\text { cancer }\end{array}$ & $22-57$ & vascular port & 16 \\
\hline $\begin{array}{l}\text { small cell lung } \\
\text { cancer }\end{array}$ & $10-39$ & dialysis catheter & 5 \\
\hline lymphomas & $1-27$ & fibrosing mediastinitis & $2-9$ \\
\hline "other metastases" & 19 & Mustard's operation & 5 \\
\hline $\begin{array}{l}\text { other } \\
\text { adenocarcinomas }\end{array}$ & $3-15$ & $\begin{array}{l}\text { primary thrombosis of the } \\
\text { superior vena clava }\end{array}$ & $1-5$ \\
\hline $\begin{array}{l}\text { germ cells } \\
\text { carcinomas }\end{array}$ & $2-6$ & retrosternal thyroid goiter & 3 \\
\hline $\begin{array}{l}\text { pleural } \\
\text { mesothelioma }\end{array}$ & $1-7$ & tuberculous lymph vasculitis & 2 \\
\hline
\end{tabular}




\begin{tabular}{|l|c|l|c|}
\hline thymoma & $1-3$ & Behçet's disease & 2 \\
\hline sarcomas & 2 & pacemaker implantation & $1-2$ \\
\hline $\begin{array}{l}\text { oesophageal } \\
\text { cancer }\end{array}$ & 2 & $\begin{array}{l}\text { haematoma following surgical } \\
\text { treatment of aortic dissection }\end{array}$ & 1 \\
\hline angiomyolipomas & 1 & thoracic aorta aneurysm & 1 \\
\hline
\end{tabular}

Prognosis in SVCS (superior vena cava syndrome) depends on the diagnosis of the main disease. Nevertheless, in the case of small cell lung cancer, the presence of SVCS is a beneficial factor for survival. The median survival rate for patients without SVCS is 13.7 months (12.7-14.5), whereas for patients with SVCS it is 16.1 months (13.8-20.5) [8].

The diagnosis of SVCS should entail the assessment of potential complications due to associated unrelated risk of death. Up to $30 \%$ of patients with SVCS may develop upper oesophageal varicose veins [8], whose presence in this case was confirmed by gastroscopy.

\section{CONCLUSION}

Sudden facial oedema is not always caused by angioedema and does not have to be associated with an allergy. In every case of facial oedema, a detailed history, full physical evaluation and oncological vigilance are required. In adult patients, an internal evaluation is recommended for an adequate differential diagnosis. The suspected superior vena cava syndrome should be followed by rapid diagnostics with the assessment of complications and implementation of treatment, in parallel with the diagnosis. If the diagnosis of malignant neoplasm is established, it is necessary to refer the patient urgently for further oncological treatment.

\section{References}

1. Cicardi M, Aberer W, Banerji A et al. Classification, diagnosis, and approach to treatment for angioedema: consensus report from the Hereditary Angioedema International Working Group. Allergy. 2014; 69(5): 602-16.

2. Fok JS, Katelaris CH. Angioedema Masqueraders. Clin Exp Allergy. 2019; 49(10): 1274-82.

3. Pope C, Gopala Pillai SK. Intermittent facial swelling. Case Reports. 2014; 2014. https://doi.org/10.1136/bcr2013202355-bcr2013202355.

4. Caralli M, Zubeldia J, Alvarez-Perea A et al. One of the Faces of Facial Swelling: Melkersson-Rosenthal Syndrome. J Investig Allergol Clin Immunol. 2018; 28(4): 265-7.

5. Straka C, Ying J, Kong F-M et al. Review of evolving etiologies, implications and treatment strategies for the superior vena cava syndrome. Springerplus. 2016; 5(1): 229.

6. Rowell NP, Gleeson FV. Systematic Review Steroids, Radiotherapy, Chemotherapy and Stents for Superior Vena Caval Obstruction in Carcinoma of the Bronchus: a Systematic Review. Clin Oncol. 2002; 14:338-51.

7. Lepper PM, Ott SR, Hoppe H et al. Superior Vena Cava Syndrome in Thoracic Malignancies. Respir Care. 2011; 56(5): 653-66.

8. Würschmidt F, Bünemann H, Heilmann H-P. Small cell lung cancer with and without superior vena cava syndrome: A multivariate analysis of prognostic factors in 408 cases. Int J Radiat Oncol. 1995; 33(1): 77-82.

Authors' contributions: Łukasz Moos: conceptualization, original draft preparation, original draft review and editing; Wojciech Żurek: conceptualization, original draft preparation; Katarzyna Kapeluszna: conceptualization, original draft review and editing; Zenon Brzoza: conceptualization, original draft review and editing.

Conflict of interests: Authors declare no conflict of interest.

Financial support: There was no financial support.

Ethics:

The authors had full access to the data and take full responsibility for its integrity. All authors have read and agreed with the content of the manuscript as written. The paper complies with the Helsinki Declaration, EU Directives and harmonized requirements for biomedical journals. 